\title{
37. NEAR-BOTTOM OBSERVATIONS OF THE MIDDLE AMERICA TRENCH OFF GUATEMALA ${ }^{1}$
}

\author{
Gregory F. Moore and Peter Lonsdale, Scripps Institution of Oceanography, La Jolla, California \\ and \\ Roland von Huene, U.S. Geological Survey, Menlo Park, California
}

\begin{abstract}
Deep-tow data across the Middle America Trench and the lower part of the landward Trench slope off Guatemala provide high-resolution information on the geological setting of four Leg 67 drill sites. Our 6-kHz profiler data resolve stratified sediments seaward of the Trench floor, which we interpret as deposits of Trench turbidites that flowed part way up the seaward slope of the Trench. Reflectors in the Trench fill are laterally continuous and relatively undisturbed. The Trench is segmented into diamond-shaped basins by ridges that intersect it at oblique angles. The acoustic stratigraphy in the Trench fill in these sub-basins is different on either side of an oblique ridge. A mound of variable height and width occurs at the base of the lower Trench slope; the mound could be either deformed Trench strata or an accumulation of debris that slumped from the Trench slope. The lower part of the landward Trench slope is steep and is linear along strike. There is no evidence on our $6-\mathrm{kHz}$ or side-scan sonar data of large gravity slides in this area. Slope sediments are ponded on a bench along the landward Trench slope. They are acoustically stratified, but are not as continuous laterally as are the Trench strata. The structure parallel to the strike of the Trench slope is variable, with many small-scale folds and faults.
\end{abstract}

\section{INTRODUCTION}

IPOD/DSDP drilling in the Middle America Trench off Guatemala was undertaken using a relatively complete suite of marine geophysical data (Seely et al., 1974; Ibrahim et al., 1979; McMillen et al., in press; Ladd et al., 1978 and this volume; von Huene et al., Geophysical Observations, this volume). However, the resolution of surface ship seismic-reflection and wide-beam bathymetric data collected along widely spaced tracks is insufficient to detect some critical structural relations. For instance, high-resolution bathymetric data obtained after drilling (Aubouin et al., 1981, and Seabeam Survey, this volume) demonstrated that a previously identified series of ridges intersects the Trench axis obliquely rather than paralleling the Trench axis off Guatemala. Difficulties in interpreting the results of the drilling data (von Huene et al., 1980) have led to reprocessing for greater detail and reinterpretation of some seismic data in this area (von Huene et al., Geophysical Observations, this volume).

In September 1981, we conducted a near-bottom survey of the Middle America Trench floor and the lower slope of the Trench off Guatemala (Fig. 1) using the deep-tow instrument package of the Marine Physical Laboratory, Scripps Institution of Oceanography. During our survey we used a narrow-beam $125-\mathrm{kHz}$ bathymetric profiler, a $6-\mathrm{kHz}$ bottom-penetration profiler system, and side-looking sonars. The deep-tow fish was kept approximately 100 meters above the seafloor and generally was navigated using three or more bottommoored transponders. The relative navigational accuracy is good to within 10 to 50 meters. The location of

\footnotetext{
${ }^{1}$ Aubouin, J., von Huene, R., et al., Init. Repts. DSDP, 67: Washington (U.S. Govt. Printing Office).
}

the survey site on the Earth's surface was done by least squares fitting of satellite fixes to ship-transponder fixes; this location is reliable to within $\mathbf{4 0 0}$ meters. In this chapter we describe briefly the bathymetric and $6-\mathrm{kHz}$ profiler data as an aid to the interpretation of the Leg 67 drilling results.

\section{MORPHOLOGIC DATA}

The deep-tow bathymetric chart (Fig. 2) was produced by reading depths from the $125-\mathrm{kHz}$ narrow-beam echo sounder records and plotting these depths, along with features noted on the side-scan sonars, on the final transponder-navigated track. The track was then fit to a large-scale version of the Seabeam chart (Aubouin et al., Seabeam Survey, this volume), and contours were interpolated between deep-tow lines using the Seabeam data. We found that the latitude-longitude coordinate systems of the two data sets did not match. Because the deep-tow survey continued for four days and our satellite fixes were related back to a fixed transponder network, we believe that our navigation is superior to that of the Seabeam chart. We found an excellent fit of the two data sets by shifting the coordinate systems of the Seabeam chart. The point of intersection of latitude $12^{\circ}$ $40^{\prime} \mathrm{N}$ with longitude $90^{\circ} 55^{\prime} \mathrm{W}$ on the Seabeam chart should be translated southeast by 800 meters along a line oriented at $147^{\circ}$, and the coordinate system should then be rotated clockwise $2^{\circ}$.

The oblique ridges recognized on the Seabeam data intercept the Trench slope at an angle of approximately $20^{\circ}$. As noted by Aubouin et al. (1981, and Seabeam Survey, this volume), the ridges break the Trench into distinct, diamond-shaped basins, but do not appear to disrupt the remarkably linear trace of the Trench lower slope.

The lowermost portion of the Trench slope is very steep (ca. $15^{\circ}$ ) from the Trench depth of greater than 


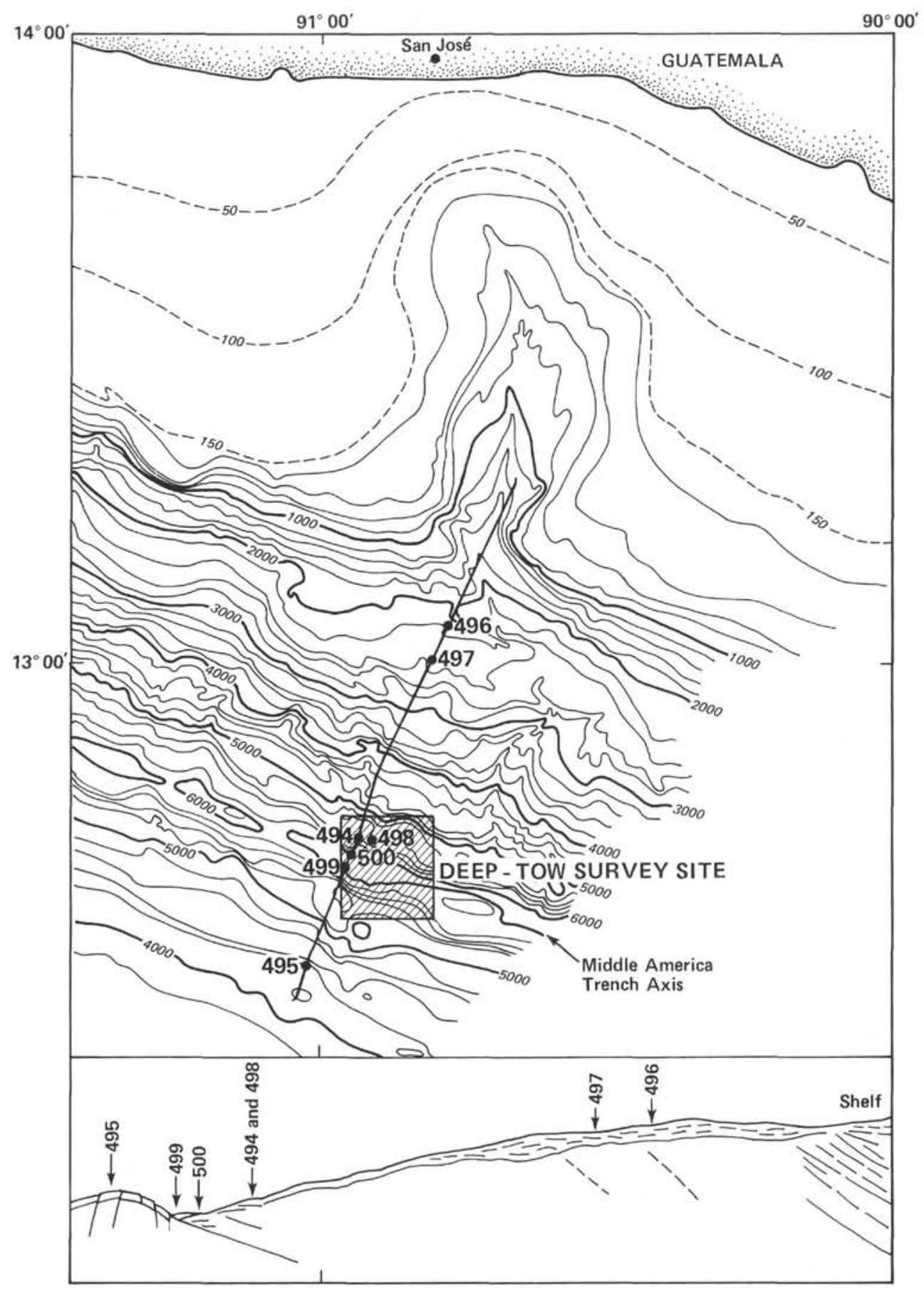

Figure 1. Bathymetric chart of Leg 67 drilling area off Guatemala, showing the location of the deep-tow survey.

6000 meters to a bench at approximately 5500 meters. This bench, on which Sites 494 and 498 were drilled, appears to have a topographic trend approximately parallel to the trend of the lower Trench slope.

\section{6-kHz PROFILER DATA}

Differences in sedimentation patterns in our survey area were illustrated on a facies distribution-structure map (Fig. 3). The major subdivisions of Trench seaward slope, oblique ridges, Trench floor, and Trench land- ward slope are clearly delineated by differences in structure and sediment distribution. Data from each area are discussed individually in this section.

\section{Trench Seaward Slope}

The oceanic crust of the Cocos Plate is highly fractured by bending stresses as it enters the Middle America Trench (Aubouin et al., 1981). Offsets along normal faults seaward of the Trench are as great as 100 meters (Fig. 4). Patches of acoustically transparent sediments 


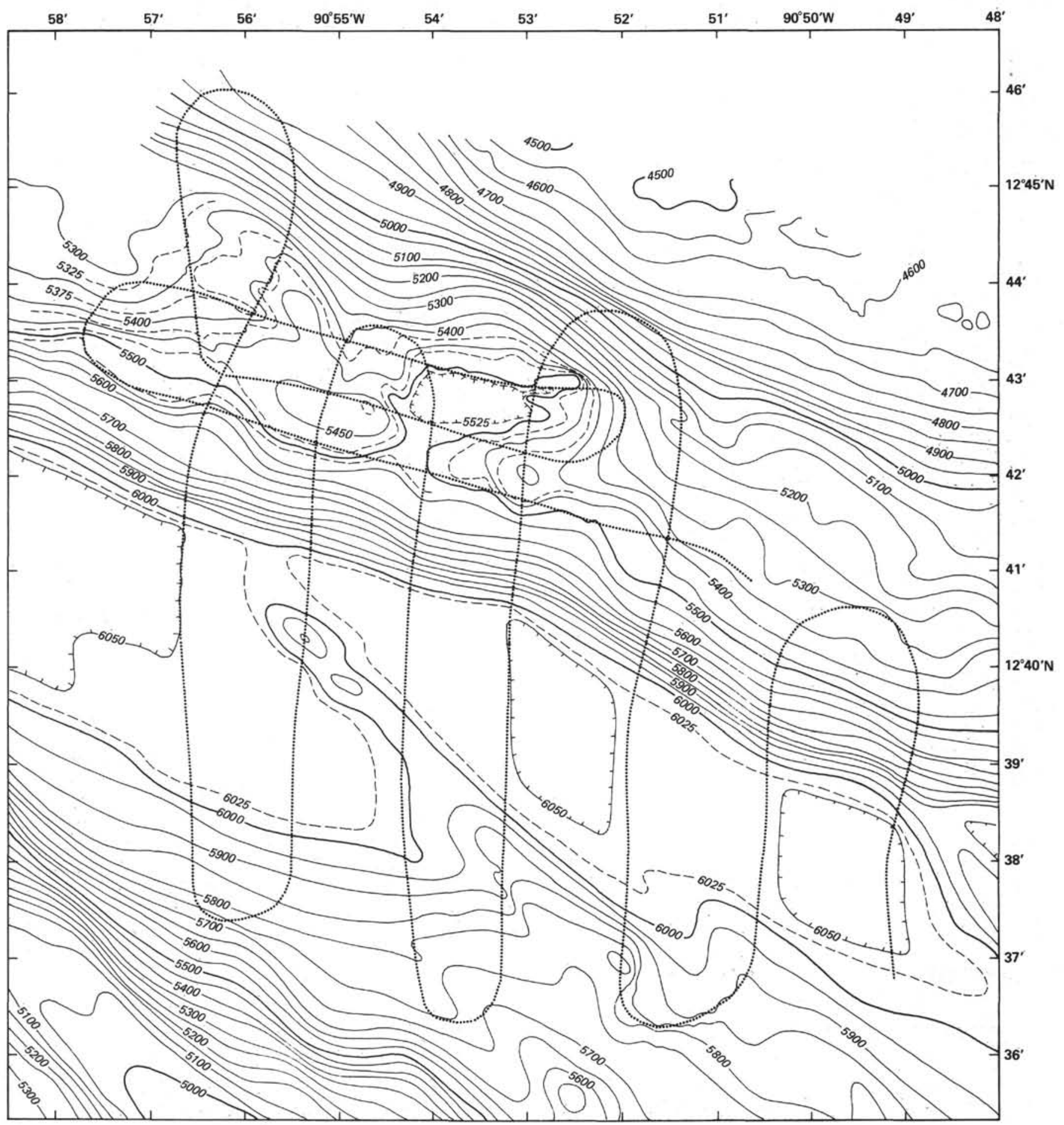

Figure 2. Bathymetric chart of the deep-tow survey area. (Contour interval is $50 \mathrm{~m}$. The primary data source is deep-tow bathymetric soundings along dotted lines. Contours were extrapolated between survey lines using deep-tow side-scan sonar data as well as the Seabeam contour chart of Aubouin et al. [Seabeam Survey, this volume].)

up to 20 meters thick occur in topographic lows and on flat areas.

Ponds of stratified sediments that closely resemble the Trench fill in acoustic character (see the next section) are common on benches of the seaward slope. Some profiles show that these stratified sediments are continuous with the Trench fill (Fig. 4B), indicating that the layered sediments may represent the distal ends of turbi- dites that have climbed up the ramps formed as the oblique ridges entered the Trench, allowing Trench turbidites to be deposited seaward of the Trench floor.

\section{Oblique Ridges}

The basement of the oblique ridges is broken by normal faults that dip both landward and seaward, thereby producing the horst topography of the ridges (Fig. 5). 


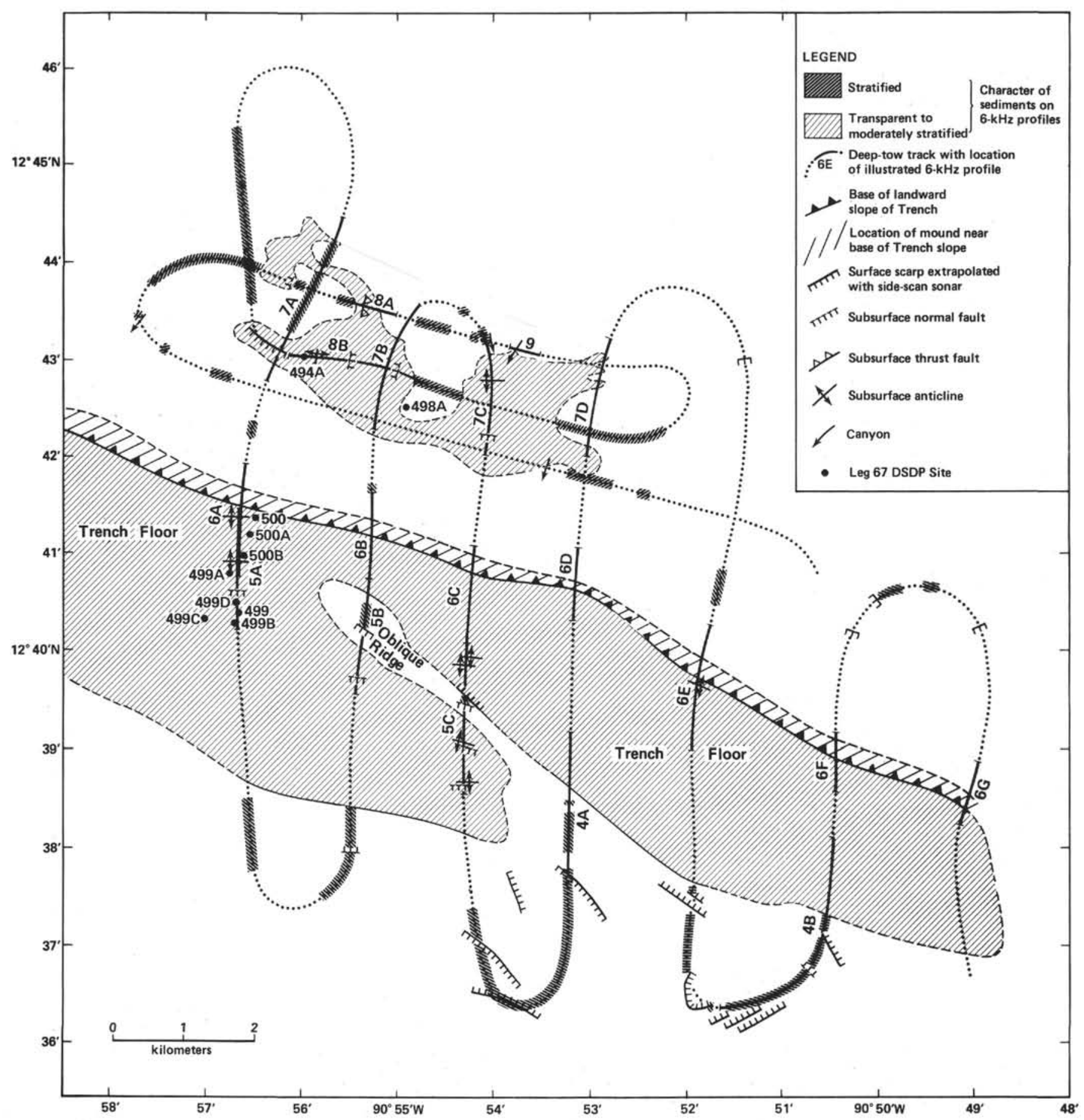

Figure 3. Structure and acoustic facies map of deep-tow survey area. (Data from deep-tow 6-kHz profiler and side-scan sonars.)

The type of sediment cover on the ridges apparently is dependent upon the height of the ridge above the adjacent seafloor. The profile in Figure 5B shows that the northwest part of the ridge is elevated more than 500 meters above the adjacent seafloor and indicates that the ridge has a very thin covering of nonstratified but transparent sediments. The southeastern crossing of the ridge (Fig. 5C) shows a relief of less than 100 meters and a sediment cover of stratified sediments that is continuous with the Trench fill. The Trench sediments on- lap the ridges on both their landward and seaward sides, demonstrating that the topography was produced seaward of the Trench and has been transported into the Trench axis with little disturbance after arriving there.

\section{Trench Floor}

The Trench floor is filled with stratified sediments that exhibit continuity of reflectors over long distances. The Trench fill thins at its seaward edge and onlaps the oceanic crust and its sediment cover. In the middle of 
A
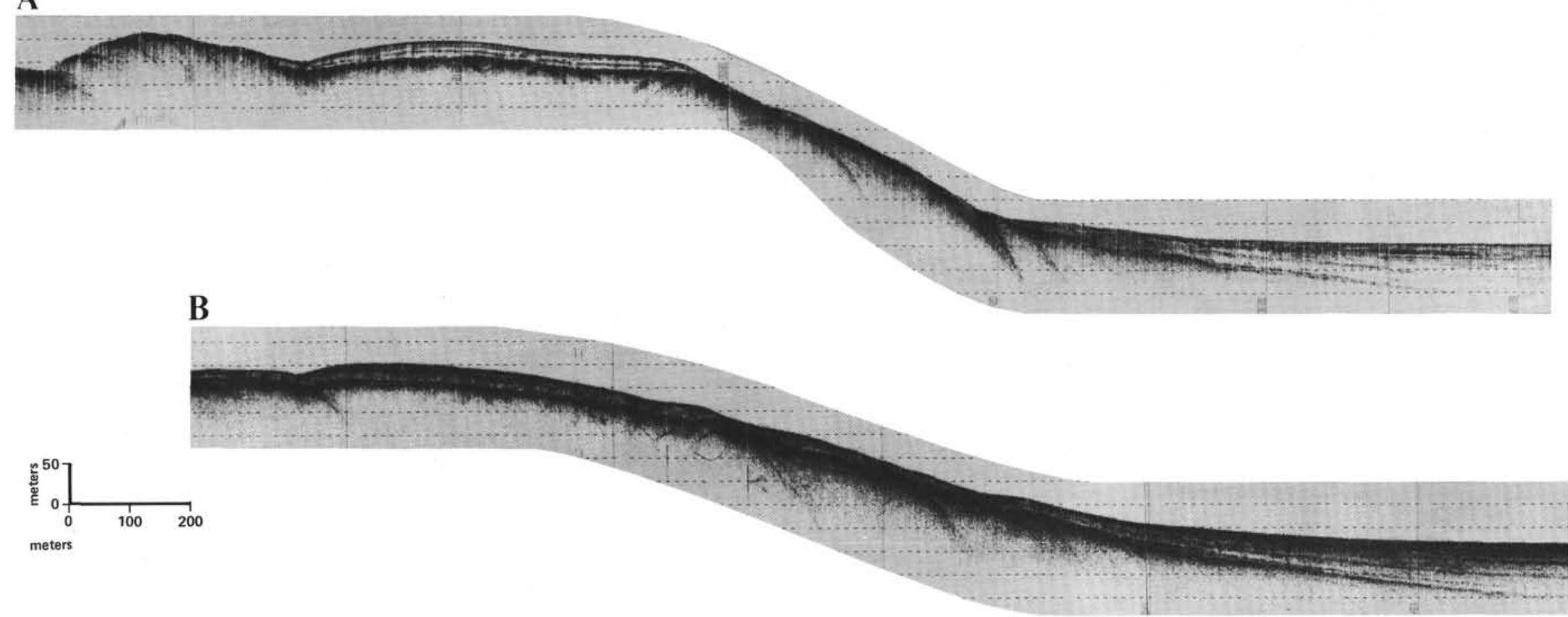

Figure 4. A and B. Bottom-penetrating $(6-\mathrm{kHz})$ profiles across the seaward slope of the Trench. (Location is shown in Fig. 3.) 


\section{South}

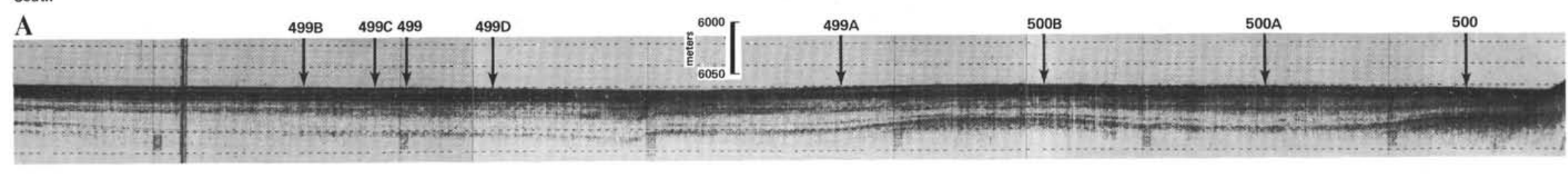

North
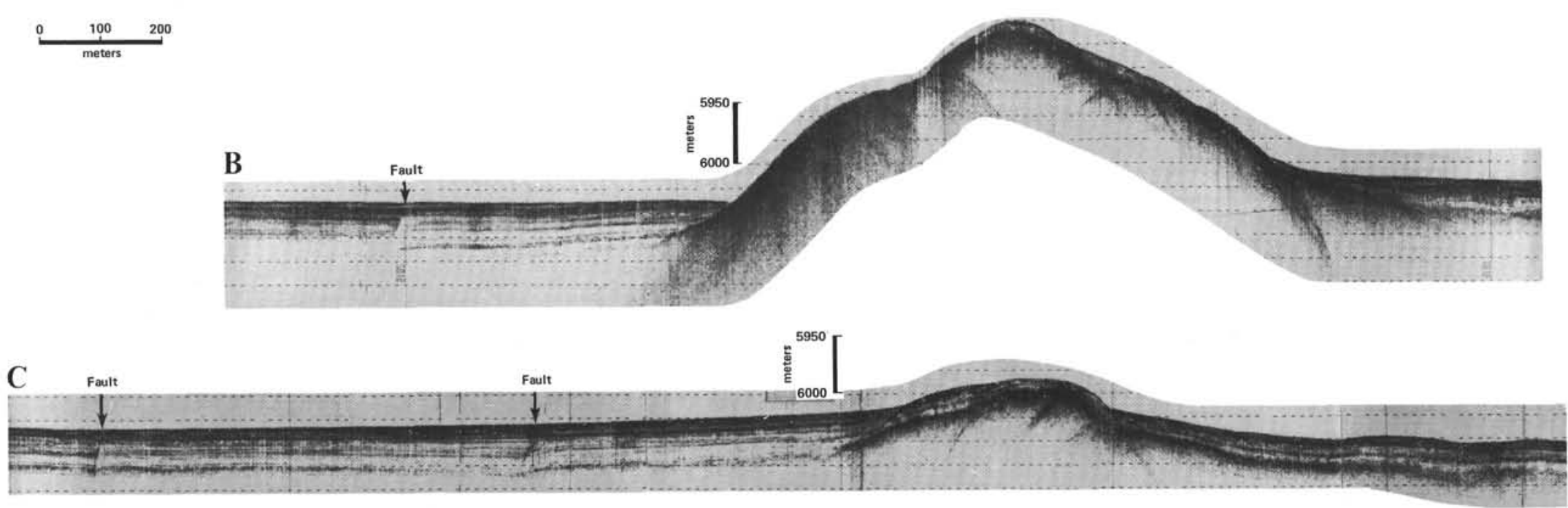

Figure 5. A-C. Deep-tow 6-kHz profiles across the Trench floor and the oblique ridge intersecting Trench floor. (Note the differences in acoustic stratigraphy on opposite sides of the oblique ridge. Location of the profiles is shown in Fig. 3.) 
the Trench, the fill is nearly undeformed (profile in Fig. $5 \mathrm{~A}$ ), except for small subsurface faults observed seaward of the oblique ridge (profiles in Figs. 5A, B). The profile in Figure 6A shows a broad buried upwarp approximately 500 meters from the base of the Trench slope. Site 500 was drilled at the edge of this upwarp, which is probably on the seaward flank of the oblique ridge.

\section{Base of Trench Slope}

Almost all profiles across the base of the lower Trench slope show a mound 400 to 500 meters wide and 50 to 100 meters above the Trench floor at the base of the slope (Fig. 6). The surfaces of the mounds are strongly reflective and characterized by diffractions. Just seaward of the ridge on several profiles the shallow Trench sediments are thinned and uplifted relative to sediments farther seaward. The ridge configuration varies considerably along strike.

Landward of the ridge, the Trench slope is very steep $\left(14^{\circ}\right.$ to $\left.15^{\circ}\right)$ and lacks any resolvable slope sediment (Fig. 6). The slope is highly reflective and exhibits many diffractions. Diffractions indicate point reflections from rough areas, but despite this indication of roughness there are few single sharp outcrops large enough to be detected. Some sedimentation must smooth the slope enough to mask any preexisting roughness. The subhorizontal reflections beneath the lower slope bench should be truncated along the base of the Trench slope (Ladd et al., this volume; von Huene et al., Geophysical Observations, this volume), and any expression of thrust faults along the lower slope would have a similar topographic expression. Significantly, no topographic features resembling slump scars large enough to form the mounds at the base of the slope were noted on profiler or side-scan records.

\section{Bench on the Lower Slope}

The first of three benches on the lower slope along the main transect of Leg 67 was drilled at Sites 494 and 498. The pattern of deep-tow tracks defines detailed topography and shallow acoustic stratigraphy around the sites (Figs. 2, 3). The bench is about $3 \mathrm{~km}$ wide and is continuous laterally for about $22 \mathrm{~km}$ (Aubouin et al., Seabeam Survey, this volume). At the 25 -meter contour interval it has an irregular topography with closed depressions and isolated highs (Fig. 2). Short trends are obvious, but there is no pervasive structural grain. Local strong deformation is indicated by topography in Figures 7A, 7D, and 8A, whereas buried smaller offsets are noted in Figures 7A, 7D, and 8B. The lateral extent of any feature is less than the spacing of the track lines, and the strike of faults and folds must have a nonsystematic orientation (Fig. 3).

Sediment ponds on the bench show thick accumulations of stratified sediments. The reflectors in these ponds are not as laterally continuous as those in the Trench (cf. Fig. 5), suggesting that active tectonism on the slope has generated small-scale topography that precludes long-distance transport of turbidites.
Several small canyons cut the Trench slope along the bench (Figs. 3, 9). Sediment is probably transported from the slope into small ponds through these canyons.

\section{DISCUSSION}

The deep-tow data are of a scale intermediate between the seismic reflection data (Ladd et al., this volume; von Huene et al., Geophysical Observations, this volume) and the drill data, and are thus useful in integrating the geological and geophysical data sets. In this section, the deep-tow, seismic, and drill data are discussed beginning at the seaward slope of the Trench and progressing landward.

At Sites 495 and 499 , the upper 80 to 170 meters of the sediment sequence on the oceanic plate is hemipelagic mud, that is, sediment from a terrigenous source but deposited by settling from the water column. Thus the acoustic stratified sequence is probably Quaternary hemipelagic sediment. Some influence from bottom currents is suggested by the thinning of the stratified sequence in V-shaped notches (Fig. 4A and B), which represent tectonically formed canyons (Fig. 2). The stratified sediment perched on ridges of the Cocos Plate must have crossed the Trench, and some form of bottom transport appears to have accompanied deposition. Bottom transport was indicated by a turbidite layer sampled by a conventional piston core from the Ida Green during a predrilling site survey (Ken McMillen, personal communication, 1978). This phenomenon is probably due in part to the intersection of the oblique ridges with the Trench axis, causing funneling of turbidites to the outer Trench slope. It is easy to visualize this geometry with our excellent morphologic control. When considering single profiles oriented perpendicularly to the slope, however, it would appear that the Trench sediments are resting on topographic highs well above the Trench floor. A possible analog to this situation is seaward of the Peru-Chile Trench, where Prince and Kulm (1975) and Kulm et al. (1981) found Trench sediments on a ridge approximately 700 meters above the Trench floor. These Trench sediments may have transported laterally down obliquely trending structures, as suggested by Coulbourn (1981). Thus the ridges in the Peru-Chile Trench axis may have a similar origin to those off Guatemala, that is, the original topographic features could have been modified by normal faulting on the outer swell, rather than being thrust faults, as favored by Kulm et al. (1981) and Prince and Kulm (1975).

The structure seen in the 6-kHz data, when combined with the lithostratigraphy and biostratigraphy documented by the drill cores, indicates local sediment sources and depocenters. At Site 499, a 117-meter-thick Trenchfill turbidite sequence consisting predominantly of mud, muddy sand, and rare discrete sand layers was sampled. The base of the Trench fill is less than 400,000 years old (Site 499, this volume). The 50 meters of strata defined in the $6-\mathrm{kHz}$ records is therefore about 200,000 years old and predominantly a muddy turbidite in which the variation in sand content is probably the main cause of the impedance contrast that produces reflections. The 
South

A

499A

$500 \mathrm{~B}$

$500 \mathrm{~A}$

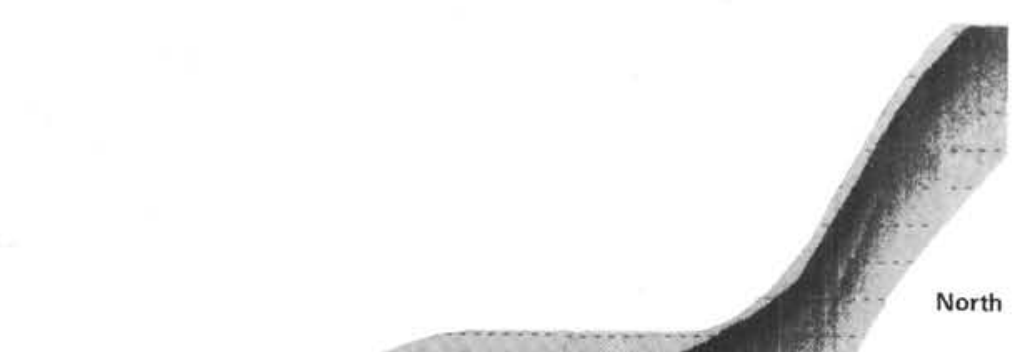

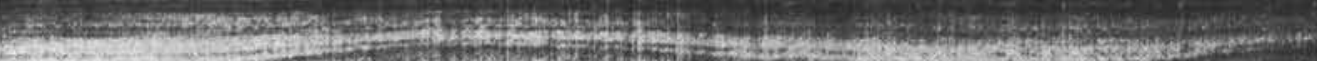

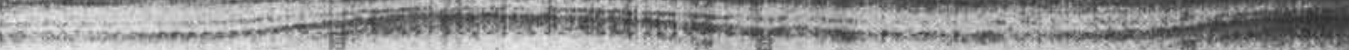

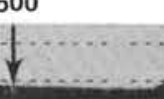

$6000 \mathrm{~m}$

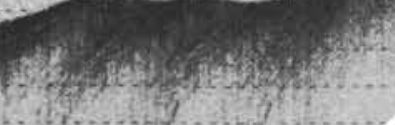
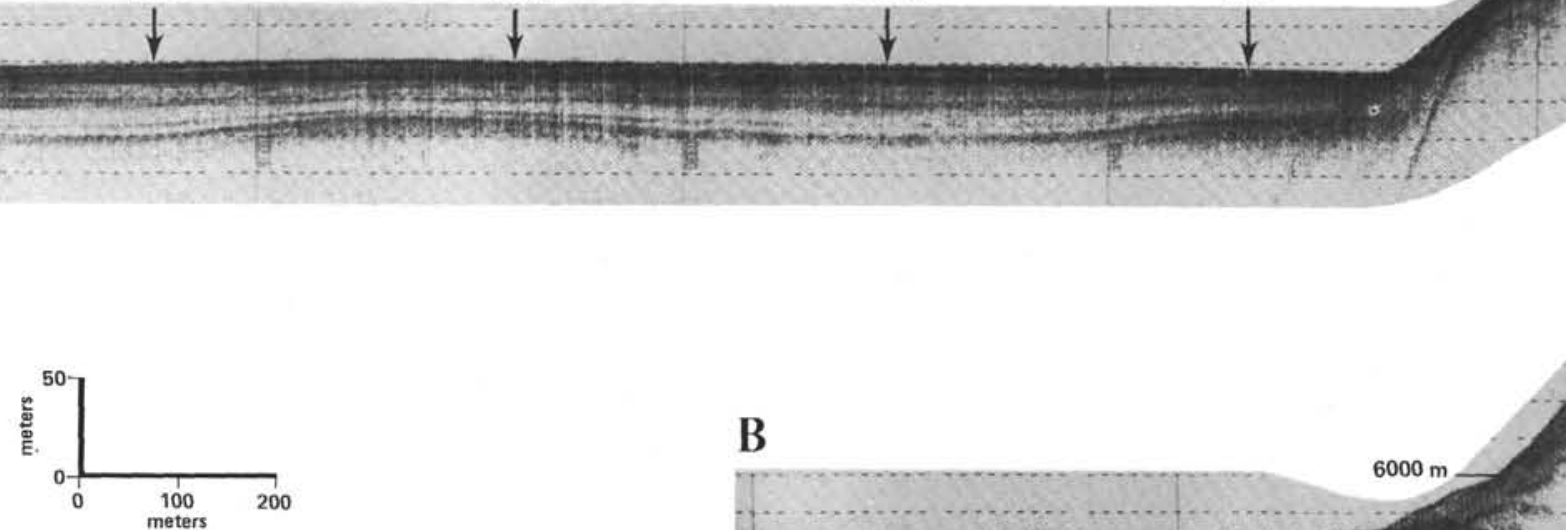

B

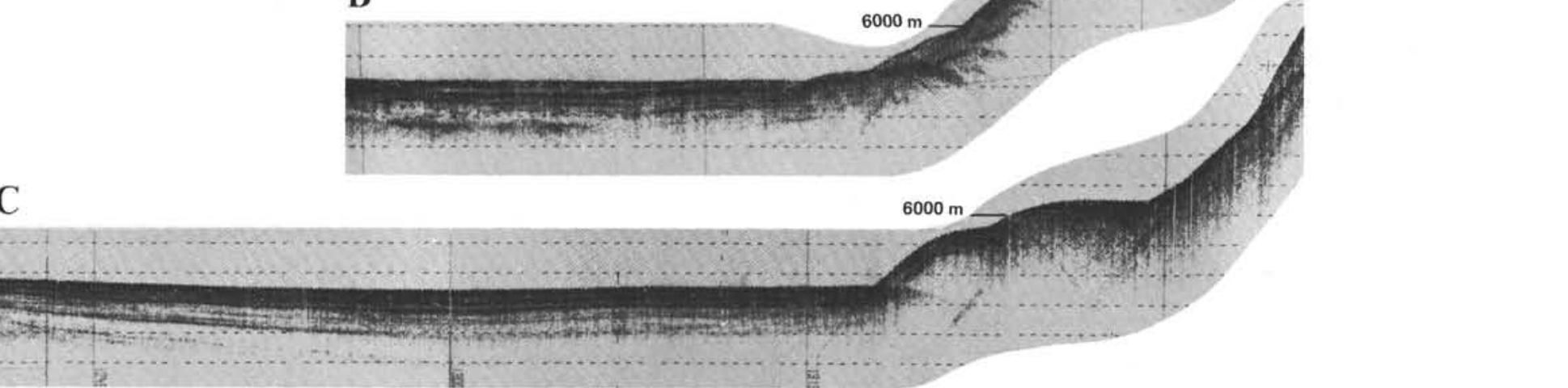

C 


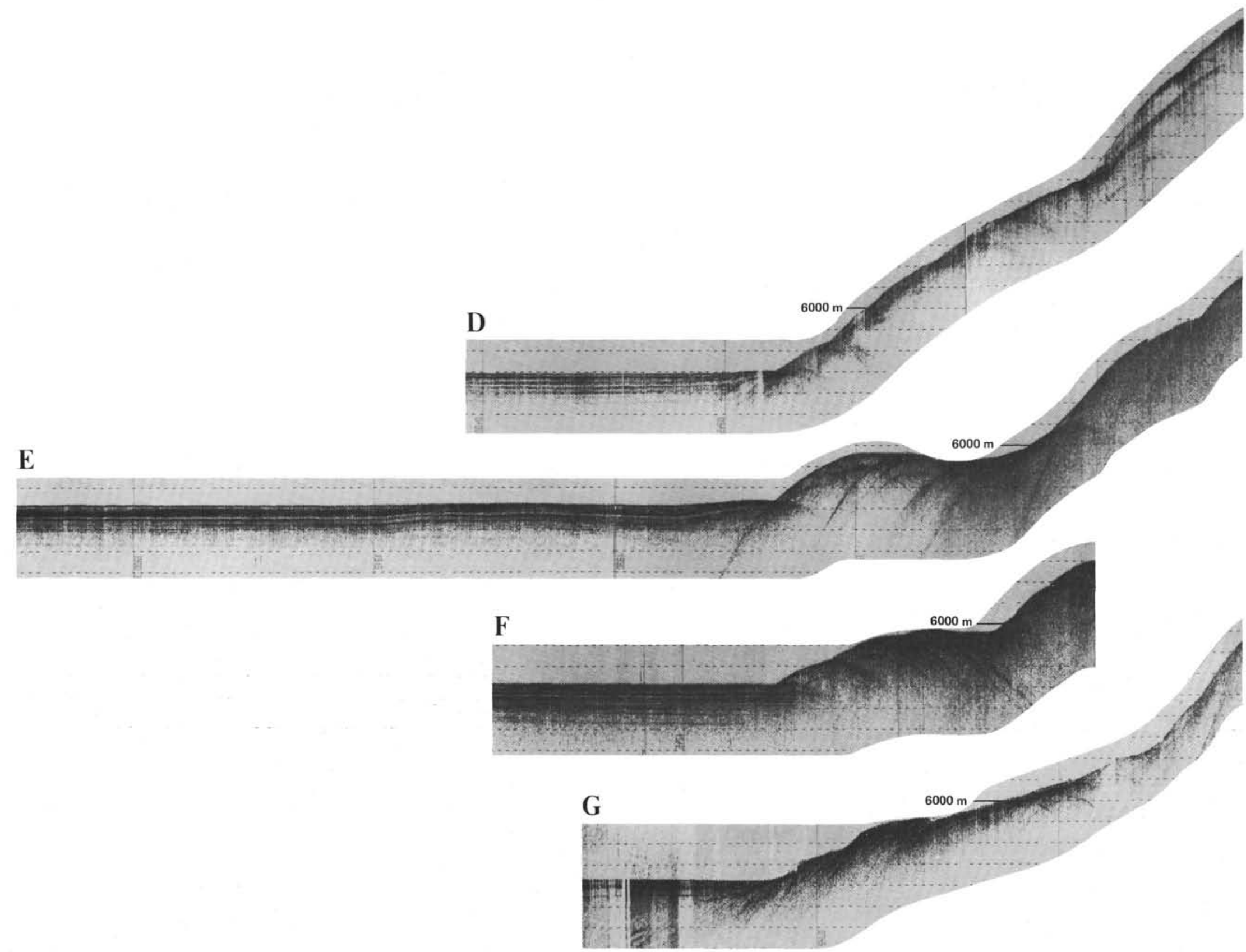



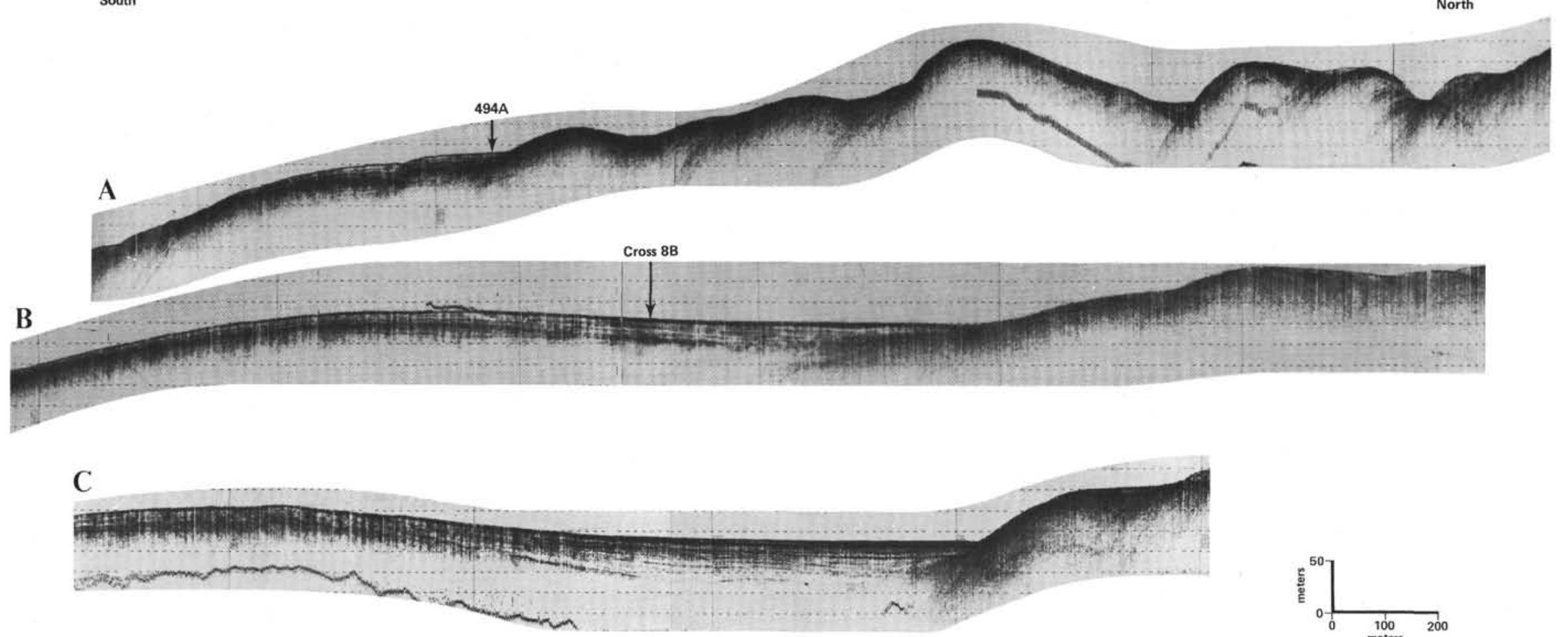

D

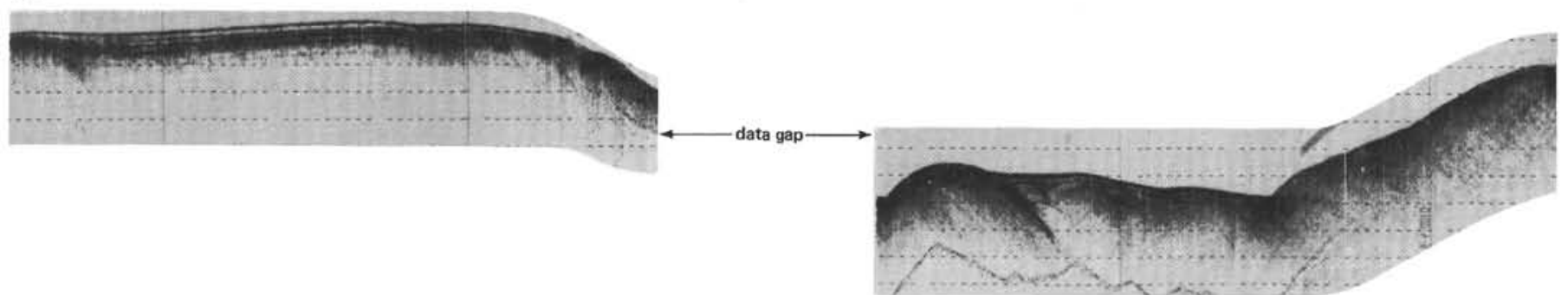

Figure 7. A-D. Deep-tow 6-kHz profiles across the bench on the lower trench slope (oriented perpendicular to strike of bench). (Locations are shown in Fig. 3.)

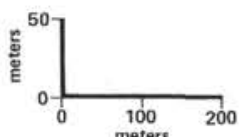


West

\section{A}

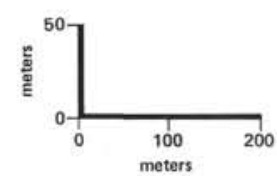

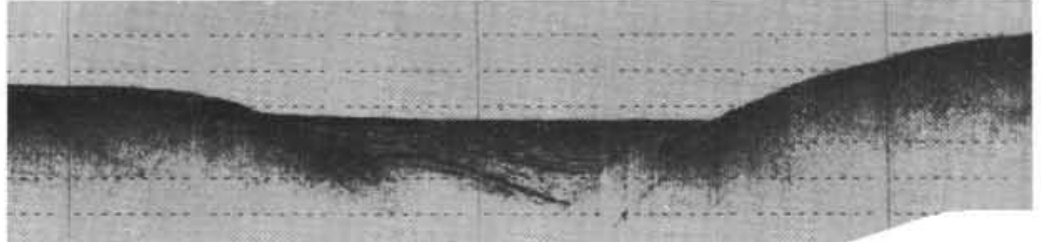

B

494A

Cross $7 \mathrm{~B}$

498A

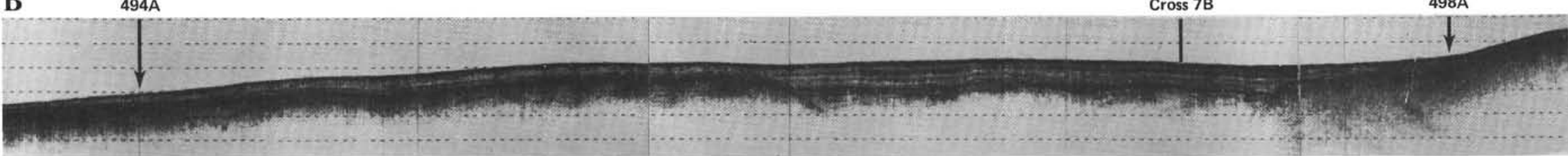

Figure 8. A and B. Deep-tow 6-kHz profiles across the bench on the lower Trench slope (oriented parallel to strike of bench). (Note the rapid change in the acoustic character of sediments and structure along the strike of the ridge. Locations are shown in Fig. 3, 
West

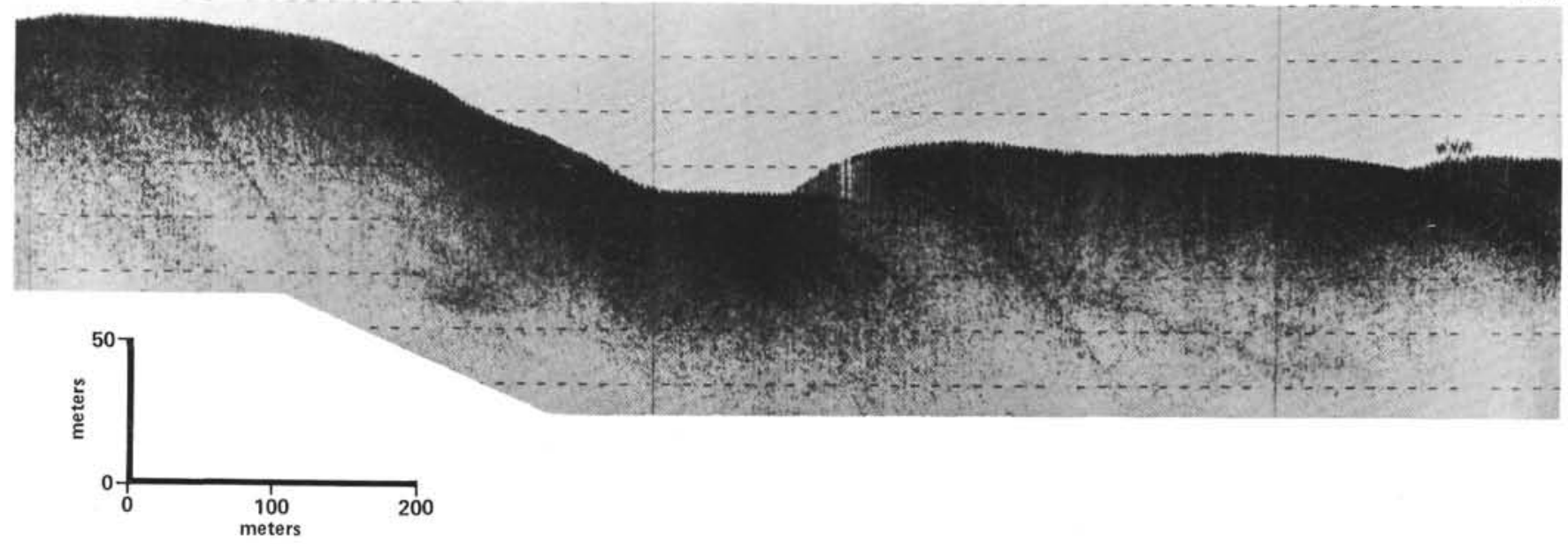

Figure 9. Deep-tow 6-kHz profile across a small canyon near the landward edge of the basin on the bench. (Location is shown in Fig. 3.)

acoustic character and sequence of reflections on either side of the oblique ridge is different (Fig. 5). Thus it appears that in the past 200,000 years each of the diamond-shaped basins between the oblique ridges that segment the Trench floor (Fig. 2) has had a local history of sedimentation different from that in other basins. The basin across which most of the deep-tow lines were made has an acoustic stratigraphy that extends laterally across the width of the basin. At the seaward edge, some of the strata run up hill as much as 55 meters (Fig. 4). No distinct distributory channels are evident. This is in contrast to Trenches where axial transport down turbidity current channels has been a major mode of sedimentation.

The ridges at the base of the Trench slope could be either a slump mass or a body of deformed Trench sediments. The Seabeam and deep-tow morphologic data demonstrate that the lower portion of the Trench slope is linear, with no indication of large slump scars. Despite the discontinuous character and variable profile of the ridges, a more positive interpretation of origin is problematical.

Minor uplift and folding of near-surface layers at the base of the Trench slope are observed in Figure 6A, C, $\mathrm{D}$, and $\mathrm{E}$. In the profile in Figure $6 \mathrm{~A}$ the tops of two folds were drilled. Cores showed no difference in the density and porosity of sediment from near the base of the slope and from as much as $20 \mathrm{~km}$ farther seaward. The folds in the Figure 6A profile may be draped over deeper structure because Holes 499A and 500A and B are located on the projection of an oblique ridge. At Site 500 a large normal fault was encountered that cut out about 100 meters of section (Hole 500) and is believed to be a fault developed on the seaward side of the Trench floor. However, in Figure $6 \mathrm{E}$ the fold clearly raises sediment above the level of the Trench and is difficult to interpret as a feature of differential compaction over a preexisting basement high. Thus it appears that local compressional folding affects the Trench-fill sediment, whereas other areas are not visibly affected.

Flat areas along the lower slope bench contain ponded sediment (Fig. 3) that shows acoustic stratification up to 55 meters deep (Figs. 7C, 8A). At Site 494 accumulation rates in the Quaternary are about $100 \mathrm{~m} / \mathrm{m} . \mathrm{y}$. Applying this rate of sedimentation to lower strata on the bench indicates that the deepest reflectors seen are about $0.5 \mathrm{~m} . y$. old. Thus the depressions and flatter areas of the bench that allowed sediment ponding are also 0.5 m.y. old. Locally, depression or relative uplift has continued through the time represented by the sediment section (Fig. 7C), as shown by dipping strata beneath a flatter, near-surface sequence.

\section{ACKNOWLEDGMENTS}

We thank Captain Arsenault, the crew, and the scientific party of Pluto Expedition, Leg 1, aboard the Melville. This research was supported by NSF Grant OCE80-18195. The manuscript was reviewed by Bill Coulbourn.

\section{REFERENCES}

Aubouin, J., Stephan, J.-F., Renard, V., Roump, J., and Lonsdale, P., 1981. Subduction of the Cocos Plate in the Mid-America Trench. Nature, 294:146-150.

Coulbourn, W. T., 1981. Tectonics of the Nazca Plate and continental margin of western south America, $18^{\circ}$ to $23^{\circ} \mathrm{S}$. Geol. Soc. Am. Mem., 154:587-618.

Ibrahim, A. K., Latham, G. V., and Ladd, J. W., 1979. Seismic refraction and reflection measurements in the Middle America Trench offshore Guatemala. J. Geophys. Res., 84:5643-5649.

Kulm, L. D., Prince, R. A., French, W., Johnson, S., and Masias, A., 1981. Crustal structure and tectonics of the Central Peru Continental Margin and Trench. Geol. Soc. Am. Mem., 154:445-468.

McMillen, K. J., Enkeboll, R. H., Moore, J. C., Shipley, T. H., and Ladd, J. W., in press. Sedimentation in different tectonic environments of the Middle America Trench, southern Mexico and Guatemala. In Leggett, J. (Ed.), Trench and Forearc Sedimentation and Tectonics in Modern and Ancient Subduction Zones: Geol. Soc. London, Spec. Publ.

Prince, R. A., and Kulm, L. D., 1975. Crustal rupture and the initiation of imbricate thrusting in the Peru-Chile Trench. Geol. Soc. Am. Bull., 86:1639-1653.

Seely, D. R. Vail, P. R., and Walton, G. G., 1974. Trench slope model. In Burk, C. A., and Drake, C. L. (Eds.), The Geology of Continental Margins: New York (Springer-Verlag), pp. 249-260.

von Huene, R., Aubouin, J., Azéma, J., Blackinton, G., Carter, J., Coulbourn, W. T., Cowan, D. S., Curiale, J. A., Dengo, C. A., Fass, R. W., Harrison, W., Hesse, R., Hussong, D. M., Ladd, J., Muzylöv, N., Shiki, T., Thompson, P. R., and Westberg, J., 1980. Leg 67: The Deep Sea Drilling Project Mid-America Trench transect off Guatemala. Geol. Soc. Am. Bull., 91:421-432. 